\title{
Rise of China's Developmental Peace: Prospects for Asian Hybrid Peacebuilding
}

\section{KwokChung Wong and Fujian Li}

\section{INTRODUCTION}

The previous chapters of this book have focused on exploring the changing environments of peacebuilding using hybrid peacebuilding theory. As a new player in the area of peacebuilding, and primarily focusing on Asia, the rise of China's peacebuilding is open to a great deal of debate. While China has been an extensive contributor to United Nations Peacekeeping Operations (UNPKO), the theory and practices of Chinese peacebuilding have never been made clear by the Chinese government. This chapter aims to identify the traits of Chinese peacebuilding based on its model of developmental peace and on evidence in Chinese practices on the ground. By so doing, it attempts to determine

K. Wong (凶)

Graduate School of International Culture and Communication Studies, Waseda University, Tokyo, Japan

e-mail: sunriseinnovator@ruri.waseda.jp

F. Li

Institute of Asian Studies, China Foreign Affairs University, Beijing, China e-mail: lifujian@cfau.edu.cn

(C) The Author(s) 2021

Y. Uesugi et al. (eds.), Operationalisation of Hybrid Peacebuilding in Asia, Security, Development and Human Rights in East Asia, https://doi.org/10.1007/978-3-030-67758-9_7 
whether China's peacebuilding model can be categorized as a form of hybrid peacebuilding.

An important concept to consider is that of the mid-space actors discussed in Chapter 4. These mid-space actors can help to bridge the gap between the top or national level of peacebuilding undertaken among elites and the bottom or grassroots level of peacebuilding undertaken by locals because peacebuilders use the mid-space as 'transit zones' in which peacebuilders of all levels can interact with each other (Uesugi and Kagawa 2020). Sometimes mid-space actors can function as 'gatekeepers' that reach across the different cleavages of society in the vertical, horizontal and diagonal gaps because these actors perform functions that cannot be effected by outsiders. However, while mid-space actors have the potential to become bridge-builders, they can also become peace-spoilers (Uesugi 2020), where they may impede a peace process or deny international access to their local community. It is important to understand that appearing to be a peace-spoiler does not necessarily mean that these actors aim to spoil the peace process, rather it can simply mean that they want to readjust their position or bring in new actors to increase the number of stakeholders that can strengthen the peace process, as in the case of Bangsamoro in the southern Philippines (Kagawa 2020). It is particularly important to consider the concepts of mid-space actors and adaptive peacebuilding that were introduced in Chapter 3 because China's style of peacebuilding is beginning to show the traits of these existing concepts. Adaptive peacebuilding is a process through which both peacebuilders and local communities come together to learn the means of creating sustained peace (de Coning 2018). Thus, adaptive peacebuilding operates according to the principle that peacebuilders should not lock themselves into a unified, standardised approach to peacebuilding, but should try to adapt to the unique local situation of each society in need. At times, the assumption of using a single unified approach, such as international peacebuilding as a tool to 'fix' conflict-affected societies can be a harmful mentality. In fact, sustainable peace is only likely if complex social systems fix themselves (Luhmann 1990).

This chapter aims to examine China's developmental peace and asks whether it can be recognised as a variation of hybrid or adaptive peacebuilding. The chapter also investigates whether China should continue its current approach in the future by referring to evidence provided by Chinese engagement with the post-conflict societies of Myanmar and Afghanistan/Pakistan. Given that a great deal of the extensive scholarship 
on peacebuilding is written from a Western perspective, it is imperative to consider the Chinese perspectives and mindset towards peacebuilding before dismissing the Chinese style of peacebuilding as illiberal or lacking human rights. To clarify the impact that the rise of China's developmental peace has on the environment of international peacebuilding, this chapter first examines the traits and background of developmental peace, which is followed by an analysis of how the Chinese approach is related to existing approaches of hybrid and adaptive peacebuilding. Case studies are then presented to provide evidence of Chinese developmental peace in practice in countries suffering from conflict, such as Myanmar and Afghanistan/Pakistan.

\section{Traits of Developmental Peace as Chinese Peacebuilding}

This section explains the origins of China's concept of developmental peace and how China's previous experiences in using developmental peace at home led to shaping this concept into a model of economic development-facilitated peacebuilding. There are three main reasons for China pursuing an alternative model of developmental peace to existing liberal models: (1) its own experiences of being a developing, communist/socialist country; (2) its non-intervention foreign policy; and (3) its desire to develop peace abroad to compensate for its lack of peacebuilding policy at home.

\section{World's Largest Developing Country}

China is both one of the largest economies in the world and the world's largest developing country. It not only has the largest economy in Asia, but also has the incentive to contribute to the stability of the region to ensure the realisation of President Xi Jinping's Belt and Road Initiative (BRI) in the hope that this initiative will contribute to the economic growth of China and partners in Asia and Africa. It is important to note that China is an Asian country that has taken a different path from other Asian countries (e.g. Japan) in its modernization and has not adopted liberal democracy by Western standards. This means that it is highly unlikely that China would follow what the West has been doing in relation to liberal peacebuilding. Some may also see China as one of the few remaining communist/socialist countries in the world. For example, in 
2010, the then Vice President Xi Jinping wrote a paper advocating the importance of studying Marxism with Chinese characteristics and said that its core agenda is scientific development and that the contradictions of Western capitalism would eventually lead to regression (Xi 2010). It is undeniable that Chairman Mao Zedong's China was communist, that it actively exported revolution and that it backed communist regimes overseas, such as Cambodia's Khmer Rouge (Wang 2018). However, there is little evidence of exporting revolution being shown by the Chinese government after the nation's reform and opening in the late 1970s.

Given that China is also a new player in international peacebuilding, where existing actors such as the United States (US) and Japan have already made clear achievements, to be a major contributor to such peacebuilding, it cannot simply replicate processes that previous actors have already implemented, and thus must take a different approach to provide tangible evidence that it is an active and responsible member of international society, contributing to peace. Therefore, China may take a socialist approach towards issues such as peacebuilding; however, in reality, when the Chinese government refers to China a 'socialist state', it uses this term more as part of a narrative directed towards its domestic audience. On the international stage, China's approach to peacebuilding is based on non-intervention, respect of the host country's sovereignty, and most importantly, as will be seen in the following section, provision of aid without strings attached.

Further, China's attempt to seek an alternative style of peacebuilding does not mean that desires to go against the West. In fact, it is more interested in cooperating with established norms than fighting with them. However, as Johnston (2003) states, China does not want to be simply a blind follower of the US order, even if it has been the biggest beneficiary of that order. There are two possible reasons for this: the first is national pride and the second, and arguably more important reason, is that China does not always follow rules that were made when China was mostly absent from international affairs (i.e. before 1978) (Glosserman 2020). Feigenbaum (2018) states that China prefers existing 'forms' but not always 'norms'. That is, China agrees that concepts such as peacebuilding are important; however, it does not prefer the norm of liberal peacebuilding established by Western actors when China was not participating in international geopolitics during its isolationism in the 60s and 70s. Unlike Johnston (2003), Feigenbaum (2018) considers China a 
revisionist power (ibid.), but neither of them refer to China as a 'revolutionary' power. China provides mainly supplemental institutions to the existing global institutions. For example, the Asian Infrastructure Investment Bank adds to the World Bank and the Asian Development Bank; the BRI to the South Asia Association for Regional Cooperation and the Shanghai Cooperation Organisation (SCO); and developmental peace to liberal peacebuilding. China does not intend to reject the existing forms but it operates under different norms.

\section{Non-intervention and Respect for Sovereignty}

While China itself is the largest developing country in the world, it aims to support other developing countries by using the methods it employed to lift itself out of poverty. China must provide this support in a way that respects the sovereignty of the host country, following China's non-intervention principle. This principle has guided China's foreign policy ever since it was first established in the Bandung Conference in 1955 (Ministry of Foreign Affairs [MOFA] of the People's Republic of China 2014) under the Five Principles of Peaceful Coexistence, and was reemphasised in the s Eight Principles for Economic Aid and Technical Assistance to Other Countries during Premier Zhou Enlai's tour to Africa in 1964 (Zhou 1964). However, it is important to note that non-intervention does not mean indifference, just as abstaining from a particular United Nations (UN) Security Council resolution does not necessarily mean being against the resolution. China is not against interventionism, but it must be with the host country's consent or under the mandate of the UN Security Council. Ruan (2012), a scholar at the China Institute of International Studies, states that China is against the style of military interventionism in which the West has shown. For example, the West's regime-change intervention in Libya ostensibly provided humanitarian aid and acted on the responsibility to protect (R2P), and its creation of highly complicated situations and regional strife in Afghanistan and Iraq. Ruan (2012) adds that the world needs to pay more attention to new players such as China entering the field of international peace, and specifically to become familiar with China as a new actor in international peacebuilding. China's official position in peace-related activities abroad can be summarised with Foreign Minister Wang Yi's remarks that China will continue to uphold the peaceful, legitimate and constructive nature 
of its style of conflict resolution with Chinese characteristics (Xinhua 2018b).

\section{'Developmental Peace' as Chinese Hybrid Peacebuilding}

The concept of developmental peace originated from a small group of scholars in China. One of these notable scholars is He Yin (2019b), who states that developmental peace is a significant departure from liberal peace because it is based on China's peaceful rise and international aid practices, adding that developmental peace aims to achieve political stability that is supported by strong institutions and economic development. Abb (2018) adds that developmental peace is based on China's own experience of strong state-led development and overseeing of political reforms and on China's principle of maintaining the stability of governing institutions and providing foreign aid with no political strings attached. However, Johnston (2003) notes that China is neither a blind follower nor a radical revisionist of current norms, so it is inaccurate to consider that developmental peace aims to develop into a new norm or become the antithesis of existing models of peacebuilding such as liberal peacebuilding. Rather, developmental peace mainly functions as an alternative Chinese approach to peacebuilding, particularly considering that the premise that development can facilitate lasting peace is shared by major international and Asian institutions such as the International Monetary Fund (IMF), the World Bank and the Japan International Cooperation Agency (JICA). The main difference with China's developmental peace and others is that China aims to preserve the standing political parties in the host countries, whereas liberal peacebuilding aims to create democracy in the post-conflict society through the expansion of liberal institutions. International organisations such as the IMF and the World Bank lean more towards the liberal model in holding that development will eventually lead to democratisation, as per modernisation theory (Limpach and Michaelowa 2010).

China needs to take advantage of its materialistic power and formulate an approach that will distinguish its style of peacebuilding from that of existing actors such as Japan. At the same time, it needs to uphold the non-intervention principle that forms the core of Chinese foreign policy. Numerous times in the past, the Chinese government has expressed its interest in expanding its role in international peacebuilding. For example, President Xi Jinping's New Year's Speech of 2020 highlighted the many 
domestic achievements of China, but also emphasised the importance of its BRI and of building a shared community for all humanity (Xi 2020). However, despite the positive signs of China aiming to adopt a greater role in international peacebuilding, it does not have any official doctrines or policies at home which constitute as a pillar of a 'Chinese model' of peacebuilding. Butler and Wheeler (2012) state that despite its active role in UNPKO, China has yet to play a significant role in peacebuilding. However, this lack of official statement is exactly what China needs: not a standardised template to implement in each conflict area, but a flexible and adaptive peacekeeping policy based on China's core values of development-led peace and non-intervention.

While it may appear contradictory to connect developmental peace (which would be likely to lead China to engage in top-down governmentto-government approaches of peacebuilding) with hybrid peacebuilding (which requires a bottom-up grassroots approach), the superficial disconnect between China's developmental peace and style of liberal peacekeeping have been rapidly changing as China engages with more complex Asian conflicts. In fact, in practice, China's developmental peace has been adopting a similar eclectic approach to the approach adopted by hybrid and adaptive peacebuilding. As stated in the Encyclopaedia Britannica (2017), eclecticism is a philosophical idea of practices that choose doctrines from a wide variety of schools of thought but do not completely adopt the parent system. When considering the US style of peacebuilding that is considered to operate according to neoliberal values, Matyok et al. (2011: 127) draw from the work of Galtung to argue that actors such as the US should use eclectic development to expand capitalist ideologies that can include both socialist and African local structures, so that it is possible to be considerate of local practices even if they do not meet the standards of liberal peace. Liberal peacebuilding models have previously been criticised for being overly top-down and institutionalised (Mac Ginty and Sanghera 2012). However, it is important to remember that nonintervention remains at the core of Chinese foreign policy despite that fact that at times, China try to enshrine local ownership when putting more focus on local issues. Given that developmental peace does not have a standardised approach, China is allowed to take an eclectic approach with the different types of conflict in Asia, which mean that developmental peace shares some traits of adaptive peacebuilding because both China's developmental peace and adaptive peacebuilding are process-oriented pragmatic approaches (de Coning 2018). 
As stated, non-intervention remains at the core of Chinese foreign policy and thus, when China is engaging in international peacebuilding, the host country's sovereignty is respected through China's developmental peace. This approach is useful when trying to build trust with the host government. For example, China's mediation between Sudan and South Sudan enjoyed support from both sides, despite Beijing's poor relationship with Juba resulting from the fact that China did not force outcomes but mainly set the stage for the conflicting parties to negotiate (ICG 2017). In addition, the RAND Corporation's research on China's foreign aid reveals that among the three types of foreign aid (i.e. grants, interest-free loans and concessional loans), China prefers to give concessional loans, while the US mostly provides grants (Wolf et al. 2013). China's preference for giving aid is vulnerable to criticism. For example, US Vice President Mike Pence made critical remarks against China, referring to its 'debt diplomacy' in Sri Lanka (The Hudson Institute 2018). The West does not consider China a democracy, so traditional donors such as the US sometimes become sceptical of Chinese practices abroad. In fact, China is similar to Japan in relation to providing foreign aid. In addition, accusing China of engaging in debt diplomacy is simplistic because China has forgiven significant debts of its partners such as Cuba and Cambodia (Rapoza 2019). As stated, this is similar to Japan, who in 2012 forgave US\$3.72 billion worth of debt for Myanmar and restarted loans (Reuters 2012).

The feature that most differentiates developmental peace from existing models of peacebuilding is its 'no political strings attached' policy. All types of government can receive Chinese aid, so long as the recipient government respects the One China Policy by not recognising Taiwan. For China, regardless of the recipient's type of government, all countries should enjoy equal rights and opportunities for development. This also connects to the concept that is introduced later in this chapter, whereby China focuses on the right to development as a basic human right. Other Asian countries such as Japan displays a similar style. For example, in 2018, Japan was criticised by the West for continuing to provide developmental aid to Cambodia despite Prime Minister Hun Sen's move towards authoritarianism, which discouraged most Western actors from engaging with Cambodia (Kasai and Adams 2018). Given that China is not a member of the Organisation for Economic Co-operation and Development (OECD), it has even fewer restrictions on the type of recipient government to which it can provide aid, which allows China 
more flexibility in how it supports the development of other developing countries. As a new player in international peacebuilding, China must use this flexibility to its advantage to engage with countries such as Myanmar, Pakistan and Afghanistan, with whom Western countries may have difficulty directly engaging. To some extent, this can be considered a unique 'niche' for peacebuilding of non-Western countries such as China and Japan.

Thus, China's developmental peace is based on its own experience as the largest developing country in the world that does not pursue the liberal model of peacebuilding. Instead, China adopts a more processoriented pragmatic approach to peacebuilding, maintaining the firm belief that all countries, regardless of their government type, should enjoy the benefits of economic development, and that such development will facilitate lasting peace in conflict-affected societies. China is not a member of the OECD and is less constrained by existing international institutions in relation to providing foreign aid to developing countries. However, given that it is a new player in the field of peacebuilding, China still has many weaknesses compared with experienced players such as Japan. Later, this chapter discusses that China does not have the necessary nongovernment organisations (NGOs) to replicate the Japanese model, and this has resulted in hindering the ability of the Chinese to deliver effective development aid directly aimed at grassroots operations. The following two case studies examine the application of China's developmental peace in the post-conflict societies of Myanmar and Afghanistan to provide understanding of developmental peace in practice.

\section{Case Studies}

The following two case studies of Myanmar and Afghanistan/Pakistan explore the practice of developmental peace in post-conflict societies. Strictly speaking, both Myanmar and Afghanistan (with some parts of Pakistan) have ongoing conflicts that require careful attention from international society. The developmental peace conducted in these countries has induced a shift in the Chinese approach from non-intervention to what Lin (2019) refers to as 'constructive intervention'. The following case studies provide understanding of Chinese peacebuilding on the ground in conflict-affected societies to provide evidence that China's developmental peace resembles existing hybrid peacebuilding models. 
The case studies identify the unique Chinese characteristics of developmental peace as well as its shortcomings.

\section{Myanmar}

\section{Background}

China shares a border with Myanmar. As neighbours, Sino-Burmese official relations began in 1950, shortly after the establishment of the People's Republic of China. China and Myanmar often call each other 'paukphaw', which translates to 'sibling' or 'intimate', demonstrating that the two countries have enjoyed close relations ever since their diplomatic relations were established (Geng 2006). China's engagement with Myanmar is also based on the Sino-Burmese Joint Declaration (signed 29 June 1954), which emphasised that China and Myanmar's relations should be based on the Five Principles of Peaceful Coexistence (ibid.). That is, China approached Myanmar with a policy of non-intervention. However, China's non-intervention approach to Myanmar encountered difficulties when constant ethnic fighting between Myanmar's armed ethnic groups and the Tatmadaw (Myanmar military) began spilling over the Chinese border, killing Chinese civilians and damaging Chinese property. In March 2015, four Chinese citizens were reported by the Chinese state media to have been killed in a misjudged bombing by the Myanmar air force, and two months later, another mistake killed five more citizens and injured more (Panda 2015; Tiezzi 2015). In addition to fighting spilling over into China, there has been a surge of refugees crossing the China-Myanmar border, which compelled China to take more robust actions to address the problem of the ethnic conflict in Myanmar.

A turning point for Sino-Burmese relations was when Aung San Suu Kyi became the state counsellor of Myanmar in 2016, ruling through a civilian government alongside Senior General Min Aung Hlaing, who has been Myanmar's commander-in-chief since 2011. At that time in 2016, the Chinese government considered how Aung San Suu Kyi becoming state counsellor would change the political situation in Myanmar and how China should react to the shift in Myanmar's new political environment. Zhang (2020) claims that with the rise of Aung San Suu Kyi, Myanmar became a diarchy, but the same problems (e.g. ethnic tensions and economic underdevelopment outside the capital) remained despite finally having a civilian-led government, alongside the military government of Myanmar. He adds that the eight occasions on which President Xi 
Jinping met with Aung San Suu Kyi and the four times he met with Min Aung Hlaing were mainly about addressing ethnic tensions in Myanmar (ibid.). This demonstrates that China recognises that the crux of Myanmar's conflicts is centred on the various ethnic groups that have been in conflict with the Tatmadaw, and that if China is to realise its geopolitical, strategic and economic incentives in the BRI, it cannot remain a side player in Myanmar, adhering to its principles of non-intervention, but would have to directly engage in Myanmar's internal conflict.

While most Western media outlets have focused their attention on the humanitarian crisis with the Rohingyas in Rakhine State, other ethnic minorities, such as the Wa and Kachin minorities, have also been engaged in armed conflict with the Myanmar government. Therefore, the situation in Myanmar requires a targeted approach that needs to adapt to the local situation of the many ethnic groups.

\section{Developmental Peace in the Mid-Space}

When considering locating mid-space actors in the ethnic conflicts of Myanmar, China recognises that ethnic tensions are at the heart of most conflicts in Myanmar. Thus, the armed militia of these ethnic groups, such as the United Wa State Army (UWSA), are gatekeepers in the mid-space in Myanmar, and China often must go through these players to engage directly with the grassroots groups. However, the importance of China's close relations with and potential leverage over the Tatmadaw cannot be understated because China is one of the few international actors that have the potential to mediate ethnic conflicts in Myanmar. Sun (2019) claims that over the six years of Chinese mediation in Myanmar, China came to the conclusion that the distrust between the Myanmar government and the country's ethnic groups was too great for any negotiations related to power sharing to occur or to have any positive effect, and topdown negotiations provided little incentive for locals to support the peace process.

Thus, China has sought to transform the relations between the Tatmadaw and the armed ethnic groups through economic development and to reduce the incentives for fighting. China considers that through this approach, the Tatmadaw will be forced to realise that they can no longer defeat armed ethnic militias permanently, thus allowing ethnic groups to be beneficiaries of economic development, which will increase the resilience of these groups to conflict caused by the scarcity of resources. China's developmental peace supports this process by bringing 
Myanmar into the BRI megaproject, for example, through the construction of the China-Myanmar Economic Corridor (CMEC), which will encompass Tengchong city and Kachin State's capital Myitkyina, the Ruili-Muse gate of northern Shan State and the Mengding-Chinshwehaw gate, close to Wa and Kokang (Sun 2019).

Returning to the example of the UWSA, the border province of Wa State has received such extensive development through Chinese investment that it resembles a Chinse province more than it does Myanmar. A report by the BBC reveals that Wa State uses the Chinese Yuan as its currency, Mandarin is widely spoken in the state, and basic infrastructure such as water, electricity and even mobile telephone signals are provided across the border from Chinese companies (Fisher 2016). The report adds that the UWSA protects Wa State from the Tatmadaw and that Wa State has enjoyed prosperous relationships with the Chinese owing to its proximity with China (ibid.). For Chinese development to penetrate on the ground in Myanmar (or in the case of the Wa State, to penetrate across the border), China must also have considerable leverage over the UWSA. In fact, the UWSA is armed by the Chinese, and China uses this army as a buffer against the Tatmadaw to push for potential benefits elsewhere in Myanmar, for example, with the Kyaukpyu Port oil pipeline in Rakhine State (Lintner 2019). Given that it is armed with sophisticated military hardware from China, it is unlikely that the UWSA can be defeated by the Tatmadaw. Thus, the two conflicting parties should be more compelled to negotiate, and without fighting, the Wa State's grassroots have the opportunity to enjoy many of the beneficial effects of Chinese development as long as China maintains positive relations with the UWSA.

In the Kachin state, China has assumed the role of a mediator between the Kachin Independence Organisation and the Myanmar government. Without China, it would have been difficult for any talks to occur between these two parties because they harbour a great deal of distrust of each other (Sun 2013).

It is also important to consider the position that the Tatmadaw takes in the ethnic conflicts in Myanmar. Just as the armed ethnic militias are gatekeepers that can allow or prevent Chinese development from reaching their people, the Tatmadaw can also act as a gatekeeper. With the rise of Aung Sun Suu Kyi's civilian government, Myanmar was effectively turned into a diarchy. Therefore, it is important for outside actors such as China to maintain close relations with both the civilian and the military government of Myanmar. China has also armed the Tatmadaw over the years. 
Chen and Ning (2020) argue that Beijing needs to stop prioritising the economic benefits of arms sales to Naypyidaw and consider halting these sales because there have been many cases where China has suffered casualties from the spillover effects of the war. If China stops the supply of arms, it would be unrealistic for the Tatmadaw to defeat all the armed ethnic groups in Myanmar, compelling parties at conflict in Myanmar to make peace and work together for economic development.

This principle also applies to the UWSA because they are also armed by the Chinese, and as fighting continues, leading to the stagnation of Chinese development in Myanmar, China should feel obliged to use its leverage over the Tatmadaw and the UWSA to negotiate for peace. Reporting on development in Myanmar, the Irrawaddy (a Burmese newspaper) states that recently pledged 4 billion yuan (US\$580 million) over three years to support Myanmar's economic development, and that between 2014 and 2019, China invested a total of 4.9 billion yuan (US\$690 million) focused on the sectors of infrastructure, agriculture and education (Thiha 2020). Without positive relations between China and both the civilian and the military governments of Myanmar, Chinese development aid cannot reach the grassroots. Without positive relations with mid-space actors such as the UWSA, China would not be able to access Wa State despite its geographical proximity to the Chinese border.

Another case in which China attempts to engage in developmental peace in Myanmar is in the Rakhine crisis. With the Rakhine crisis, China has surprisingly taken a step back towards non-intervention, advocating the importance of allowing only the directly concerned parties (i.e. Myanmar and Bangladesh) to negotiate repatriation of the Rohingya refugees. The role China took between the two was that of a mediator, proposing the Three Point Plan as a three-step approach to ceasing the violence, repatriating the refugees and facilitating the economic development of the Rakhine State. However, this Three Point Plan has received criticism from international actors. For example, Joy (2018) claims that the first point of the plan, which calls for a ceasefire, is no longer relevant because the violence has mostly ceased; that in relation to the second point of the plan, China's role during the signing of the influential repatriation pact between Myanmar and Bangladesh is not clear; and that in relation to the third point of the plan, China understates the severity of the crisis by considering that it can be solved through economic underdevelopment. Human Rights Watch (2018) reported that there are no signs in Myanmar that the refugees will be safe when they return to 
Rakhine, despite China's offer to provide the Rakhine State with prefabricated homes to enable refugees trapped in Bangladesh to return (Xinhua 2018a). From the perspectives of the West, China struggles to address problems such as the Rakhine crisis. For example, it is claimed that China is not ready to tackle sensitive issues, unlike traditional donors, because the Chinese government faces similar problems at home (Richmond and Tellidis 2014).

Given the unique situation of Myanmar, in which civilian and military leaders are juxtaposed, China must constantly engage with both Aung San Suu Kyi's civilian government and Min Aung Hlaing's military government. Over the years as China has engaged with Myanmar, China has realised that ethnic groups are gatekeepers and any peace process must begin with transforming relations between the ethnic groups and the Myanmar government, particularly the Tatmadaw. This realisation demonstrates that China has adapted to the local situation of Myanmar and has aimed to transform the relations between the conflicting parties through economic development such as the BRI's CMEC to decrease incentives for fighting. However, China's use of a similar approach to effect economic development in the Rakhine State has not had with similar success.

\section{Afghanistan and Pakistan}

\section{Background}

Afghanistan and Pakistan are considered as one case study because China's peacebuilding efforts in Afghanistan cannot be divorced from China's engagement with Pakistan. This situation dates back to 1962 in the Cold War, when both Afghanistan and Pakistan expected China to play the role of a mediator, but at the time, China's Premier Zhou Enlai did not want China assuming the role (Khalil 2018). In fact, Pakistan did not become China's strategic partner until after the Sino-Indian War in 1964. In addition, when the Soviet Union invaded Afghanistan, China supported the Mujahideen insurgency against the Soviets, which resulted in strained ties between China and Afghanistan, but also Afghan's belief that Pakistan was behind the insecurity in Afghanistan (ibid.). Further, there are many current reports that the Taliban is in the Western Balochistan province of Pakistan (Notezai 2019), and the fact that Osama Bin Laden was found and killed in Pakistan in 2011 demonstrates how closely Pakistan was involved with Afghanistan and the Taliban. This also means that 
China's close relationship with Pakistan also gives the Chinese access to the Taliban.

Afghanistan shares a much shorter border with China that does with Myanmar, but the importance and implications of China's relationship with Afghanistan are no less significant than China's relationship with Myanmar. In 2001 when George W. Bush invaded Afghanistan to retaliate against the September 11 attacks, China provided moral support to the US action. However, this support was only verbal because China did not want to be seen by the Islamic world as directly supporting what was seen by many as an anti-Muslim NATO coalition, fearing that this would fuel further extremism in the Xinjiang province (Zhao 2013). It is interesting that the Chinese government decided to support (but did not provide physical support) the US during the US invasion of Afghanistan despite Sino-US relations being at an all-time low because of the 1999 bombing of the Chinese embassy in Belgrade by NATO, which occurred only two years before the September 11 attacks (Hui 2019). When the war ended, China emphasised that the post-war Afghan peace process should be 'Afghan owned and Afghan led', and the Chinese have maintained this narrative to the present day (Xinhua 2020). To support the peace process being Afghan owned and Afghan led, China's permanent representative to the UN, Zhang Jun, stated at a plenary meeting in the UN General Assembly that the Afghan-owned and Afghan-led peace process must be supported by international actors such as the US in the existing peace talks, while China would also promote peace talks through international organisations such as the SCO and through China-Afghanistan-Pakistan Foreign Ministers' Dialogues (Xinhua 2019b). China also stated that it would continue to support Afghanistan's economic development through implementing a bilateral memorandum of understanding with the BRI to help Afghanistan boost trade links in the region (ibid.).

China is interested in the peaceful resolution of the war in Afghanistan for two principal reasons. First, China wants to prevent the spillover of religious extremism from neighbouring Afghanistan into its relatively short western boarder of the Xinjiang province. Foreign Minister Wang Yi praised Afghanistan's efforts in taking effective measures against the East Turkestan Islamic Movement, and in ensuring Afghanistan's increased cooperation with China through participation in the BRI (MOFA of China 2019). However, China also wants to protect its BRI interests in Pakistan. The China-Pakistan Economic Corridor (CPEC), often regarded as the BRI's flagship project, is constantly under threat of from 
militant groups in Pakistan that have links to the Taliban (Biberman and Schwartz 2019). Chinese analysts also say China has benefited greatly from the temporary order created by the US presence in Afghanistan, and if the US is to withdraw entirely from Afghanistan, it must be done in an 'orderly fashion' to avoid creating any sudden power vacuums in the region (Zhao 2013). After the US withdrawal from Afghanistan, it will be the responsibility of regional actors such as China to support Afghanistan's reintegration into Asian economy. Thus, China's interest in order in the region and its economic interests related to the BRI in Afghanistan continue to compel China to engage proactively in aiding the peace process in Afghanistan.

\section{Developmental Peace in the Mid-Space}

Pakistan is an important strategic and economic partner for China. Economically, Pakistan provides China with the valuable Gwadar Port, which enables Chinese access to the Indian Ocean, and strategically, both countries have a common regional rival-India. In addition, China's relationship with the Afghan government deteriorated significantly when China supported the Mujahideen insurgency during the Soviet invasion. Meanwhile, Pakistan and Afghanistan have enjoyed close, but not always friendly, relations with each other in the past (Khalil 2018). For example, Pakistan often exploited Afghanistan's vulnerabilities such as its weak state and practiced predatory politics against it, such as attempting to install a mujahideen government in Kabul after Soviet withdrawal in 1989 (Akhtar 2008). As stated, during the Soviet invasion of Afghanistan, Pakistan was also accused by Afghanistan of causing the insecurity of Afghanistan. Given that insecurity in the Balochistan province in Pakistan has threatened the wellbeing of the CPEC, China needs to bring its close economic partner, Pakistan, together with a less familiar actor, Afghanistan, to jointly address the cross-border instability that could potentially threaten the BRI. In addition, Pakistan and Afghanistan have often approached China to request its mediation between the Afghan government and the Taliban, and Kabul have expressed interest in being a part of the BRI in connection with the CPEC (Bokhari 2019) if stability is attained in Afghanistan. Therefore, in theory, it is possible for China to engage Afghanistan directly, but it would be more effective to also engage Pakistan because the conflict involves a cross-border regional problem for both Afghanistan and Pakistan. Overall, China's approach to Afghanistan has three levels. On the international level, China and the US engage 
Afghanistan through international organisations; on the regional level, China engages Afghanistan through Pakistan; and on the ground level in Afghanistan, the engagement is bilateral between Beijing and Kabul, and will possibly include the Taliban.

Pakistan plays an important role of giving China access to the local Afghan gatekeepers: the Taliban. The China-Afghanistan-Pakistan Foreign Ministers' Dialogue has been conducted on an annual basis since 2017. In the first meeting between Chinese Foreign Minister Wang Yi, Afghan Foreign Minister Salahuddin Rabbani and Pakistani Foreign Minister Khawaja Muhammad Asif, the basic premises of the cooperation among these countries were outlined, emphasising the importance of bringing Afghanistan to peace through mutual trust, with the issue of counterterrorism being mentioned briefly (MOFA of the People's Republic of China 2017). In 2018, when the three foreign ministers (with the new foreign minister of Pakistan, Shah Mahmood Qureshi) met again, the issue of counterterrorism and the Taliban received greater attention (MOFA of the People's Republic of China 2018). Finally, in 2019, the three countries continued to underline the importance of counterterrorism and the greater commitment of Afghanistan to participating in the BRI (MOFA of Afghanistan 2019). Given that the Taliban insurgency is a regional problem that spills over the borders of Pakistan and Afghanistan, it is important for China to include both countries in resolving tensions in the region and the threat of terrorism. Of course, there is always the option for China to engage directly with the Taliban, but this would contradict China's principle of non-intervention if it conducted such engagement without the consent of the Afghan and Pakistani governments.

In talking with the Taliban, China emulates the approach it has taken with other parties such as Myanmar and recognises that the Taliban insurgency is the root cause of the instability in Afghanistan. While the US has also initiated talks with the Taliban, US diplomacy alone is insufficient in bringing stability to Afghanistan. For example, in September 2019, US President Donald Trump called off a scheduled meeting with the Taliban after a bomb attack in Kabul killed 11 people, including one US soldier (Sediqi 2019). Another difficulty in engaging in talks with the Taliban is that they have refused to talk to the 'puppet government' of Kabul and have demanded direct talks with the US; however, this attitude has changed considerably after the many years of fighting in Afghanistan (Jackson 2018). China's recognition of the Taliban as a 
gatekeeper is important because it shows that China has considerable adaptability in its approach to Afghanistan. It could even be argued that China is practising Track II diplomacy in this case. For example, in top-down government-to-government talks, China remains flexible in involving many stakeholders, such as Pakistan, the Afghan government in Kabul, and the US, related to the conflict, which is seen in the establishment of a Quadrilateral Coordination Group consists of China, the US, Pakistan and Afghanistan that was characterised as a peace mechanism for strengthening unity and forming consensus (Global Times 2017). In addition, China has organised direct talks with the Taliban as well, with the consent from Kabul, but specifics of these talks remain classified for now.

China realises that it cannot rely only on the top-down governmentto-government approach in Afghanistan because national identity and unity has never been strong in Afghanistan (K.R. He 2019a). For example, Dupree (2002) notes that despite the rich cultural heritage of Afghanistan, attempts to facilitate national unity have seen mixed success because Afghans took little pride in their country's heritage before the war, and even less after. Since Afghanistan's state unity is so weak, it is important for outside intervenors such as China and the US to help Afghans first to consolidate a common national identity, or at least to strive for a common goal through the establishment of a 'transformative relationship'. Kagawa (2020) argues that a transformative relationship is an asset that enables mid-space actors to connect with each other through shared norms and experiences. Through a transformative relationship, gatekeepers can help to rebuild broken trust and relationships between conflicting parties.

Jackson (2018) states that on the ground, the Taliban have relinquished their cruel and brutal ways of the past and are attempting to show a different face-that they can do everything the government can do, but better. That is, the Taliban were once peace-spoilers who denounced the US-led Afghan government in Kabul as a 'US puppet' (Sediqi 2019), but are now trying to compete with the government in Kabul as a provider of public goods to the grassroots communities in Afghanistan. Given that the Afghan government is mainly focused on the reconstruction of major cities, the rural areas are run mostly by the Taliban, who appoint village elders as civil servants to monitor schools and hospitals or collect taxes in villages, and at times, to provide connections to Kabul (Jackson 2018). The precise extent of the Taliban's control is difficult to judge, but in 
many areas, it is an accepted fact that the Taliban are in charge even without flying its flag (ibid.).

Given that it is difficult to nurture the creation of a national identity in Afghanistan in the short term, China is investing in constructing a transformative relationship between the Taliban and the government in Kabul through working towards a common goal of rebuilding Afghanistan. Because Afghanistan needs foreign aid to rebuild its war-torn country, China has already shown positive signs that it wants to incorporate Afghanistan into the BRI, connecting it with the CPEC in Pakistan. An overseas analyst on Afghanistan claims that Afghanistan's natural resources would be better exploited by neighbouring countries, and that China, with its economic resources, happens to be the only country capable of doing so (Sarwar 2020). While this may omit consideration of other potential regional actors such as India and Japan, China is definitely one of the closest sources of foreign aid for both Kabul and the Taliban if they decide to cease direct violence and to compete with each other to attract foreign aid or investment such as is offered through Chinese development projects included in the BRI. This is similar to the CMEC in Myanmar, where special economic zones could be established and where an increase in the number of stakeholders in these projects would lessen the likelihood of direct violence that could jeopardise development and lead to losing the support of the locals. Both Kabul and the Taliban could be empowered by development projects because the Taliban too have shown signs that they require local support with the help of village elders, transforming their gatekeeper role from peace-spoiler to bridge-builder.

However, it is always useful to remember that China still considers itself an outsider to Afghanistan's problems. Through the Istanbul Process, a platform created for Afghanistan to discuss regional issues with its neighbours, China has pushed for reconciliation processes for local ethnic groups in Afghanistan (Hu 2018). In relation to specific development aid, one of the first forms of infrastructure that China built in Afghanistan was hydraulic engineering, and as water begins to flow, there will be electricity and other developments (Sun 2014). For the future, President Xi Jinping has encouraged Chinese companies to actively invest in Afghanistan (ibid.), but of course these investments will only occur if the situation becomes stable in Afghanistan. Therefore, there are clear and strong incentives for the Taliban to become bridge-builders if they are competing with Kabul for governing rights of the country, as continued fighting and violence will scare investors away. 


\section{Shortcomings AND A STEP Forward}

Chinese peacebuilding through developmental peace is by no means perfect. It is a new approach that has many loopholes that make it a target of criticism from the West. One of these weaknesses is the lack of Chinese NGOs that can support the bottom-up process. China's NGOs are underdeveloped, not only because they are too tightly controlled by Beijing but also because at times, they are seen as jeopardising government aims, such that even environmental NGOs can be subjected to strict regulations (Feldshuh 2018). In contrast, many Japanese NGOs are familiar with the situation at the grassroots level (MOFA of Japan 2017) because Japan conducts its Official Development Assistance (ODA) through these NGOs and has public-private partnership organisations such as the Japan Platform that provide emergency humanitarian aid, and enable the coordination of government and private sector funding with NGOs (Japan Platform 2019). Unlike Tokyo, Beijing has not shown the same type of support for local NGOs in the host county it operates, such as Myanmar. For example, Chen and Ning (2020) argue that in Myanmar, communities that are located away from the city centres may not feel the benefits of the BRI, and thus, such communities would prefer a Japanese NGO to construct a school or dig a well in their local village.

A potential remedy for this problem is that China would substitute the role usually played by NGOs with Chinese State-Owned Enterprises (SOEs), similar to the way in which Japanese NGOs and JICA coordinate the public and private sectors to efficiently deliver ODA to the host country (JICA, n.d.). A study conducted in Myanmar demonstrates that many Chinese SOEs are conducting grassroots projects, where smaller Chinese private companies provide logistics support for larger companies while also engaging with local companies (Dunn et al. 2016). However, the problem with Chinese SOEs substituting Chinese NGOs does little to improve Myanmar's general negative public perception of China. In a policy brief written by the International Growth Centre presents evidence that Chinese companies on the ground are subject to negative bias because they are from China, and that this bias is greatly reduced when the foreign company is from Japan (Yao and Zhang 2018). In fact, Dunn et al. (2016) note that Chinese SOEs are generally aware of the environmental and social impacts of investment, but that these companies often lack the capacity to address issues related to these impacts, thus these researchers suggest that Chinese SOEs should collaborate and 
share experiences with established foreign companies on the ground. In contrast, private companies are more difficult to monitor and often rely on the knowledge of their local partners for information on environmental and social impacts of investment (ibid.). This reveals the inexperience of Chinese companies operating in grassroots development compared with experienced foreign actors such as the Japanese private sector. As China becomes more engaged in peacebuilding, these shortcomings can be addressed more effectively with closer coordination between Chinese actors and their local counterparts such as private companies and NGOs, as well as between Chinese actors and established foreign actors such as Japanese companies and NGOs.

Another common criticism directed against China is the lack of promotion of human rights. In Myanmar, Human Rights Watch (2018) criticised the rushed repatriation process of the Rohingyas, where the issue of citizenship has never been addressed. In defence of China, it can be argued that the Chinese have a fundamentally different understanding from the West of what constitutes basic human rights. While the West considers metaphysical concepts such as identity as a basis of human rights, as seen in the Rakhine crisis, China considers human rights of groups such as the Rohingya refugees are met by ensuring the equal right to live a life with dignity under the economic development that Chinese BRI projects can bring to the Rakhine State. Xinhua (2019a) (China's state media agency) reported that China, on behalf of 139 states in the UN, called for the full realisation of the right to development for all people in 2019, stating that all people should have equal rights to participate in development and ensure 'a life of dignity'. With Afghanistan, it is also possible that China will continue to engage with the government to improve the standard of living for the locals as violence ceases and development is allowed to occur.

It is also possible that Chinese peacebuilding based on developmental peace can drive the overall peacebuilding environment in the region towards being more elite driven. The Chinese style of developmental peace emphasises the fact that stable government-centred policies are most efficient in helping a developing country achieve economic development, as was true for Japan, South Korea, Taiwan, Singapore and China. Currently, there is no clear evidence that China has been in close cooperation with grassroots mid-space actors such as local NGOs. Some of China's local engagement that is not with the official government of the host country is mainly with local armed groups such as the UWSA. To 
some extent, engagement with such groups still represents a somewhat elite-driven process because the unarmed civilians do not always have a say in the decision-making process between the UWSA and the Tatmadaw. However, it is also important to recognise that local armed groups are also a type of mid-space gatekeeper. For example, Kagawa (2020) argues the importance of building a transformative relationship with Bangsamoro rebel leaders.

Another example of China focusing their relationship mainly on local elites is seen in their relationship with Pakistan's Inter-Services Intelligence (ISI) that plays a role of gatekeepers to the Taliban in Afghanistan. Taliban commanders stated that the power of the ISI is "as clear as the sun in the sky" (Waldman 2010). While they are not a puppet of the ISI, the Taliban are often at the mercy of the ISI's power and the ISI has previously arrested Taliban leaders with the aim of disrupting peace talks because Pakistan does not want peace in Afghanistan. However, without the ISI, the Taliban find it difficult to even host meetings (ibid.). Western powers have a troubling relationship with the ISI as there is little evidence that the US and international pressure has had any impact on safe havens in Pakistan for the Taliban (ibid.). Because of the ISI's profoundly important role in Afghanistan and its deep connections with the Taliban, and because of China's close relations with the Pakistani government, the Chinese are granted access to the ground level of Afghan communities under the Taliban's control. Unlike the ISI, China's main interests in Afghanistan are economic, that is, China seeks peace in Afghanistan for the sake of the BRI.

Given the amount of geopolitical competition in Asia, peacebuilding in this region may not always be based on altruistic motives. For example, the geopolitical implications of China's engagement with the Taliban in bringing peace to Afghanistan for the BRI may be only a by-product of China's close relationship with Pakistan to counter India. In addition, China may exercise its leverage on the UWSA only to prevent excessive foreign influences on Myanmar using the UWSA as a buffer with the Tatmadaw. The West, with its epistemology of liberal peace has done the same by facilitating regime change to sweep out authoritarian regimes and replace them with Western friendly democracies, giving rise to arguments that Western regimes are more interested in being agents of transformation than helping with conflict resolution (Orakzai 2015). The Chinese model is not perfect by any means, currently, China continues to collaborate with government and local elites more than with local grassroots 
groups. This may be because China itself does not have a well-developed system of civil society and NGOs to support its developmental peace on the ground. Perhaps this is where actors such as Japan who have the necessary tools such as NGOs can supplement China's efforts after China gains unique access to mid-space actors through developmental peace.

\section{CONCLUSION}

At the beginning of the chapter, we asked whether China's developmental peace represents a form of hybrid peacebuilding: the answer is yes and no. China's developmental peace has transcended its previous foreign policy principle of non-intervention, and has pushed China to engage not only with the host country's government through a top-down approach, but also with a much wider variety of local actors to pursue the bottom-up approach of hybrid peacebuilding. However, given that China is still a beginner in hybrid peacebuilding, it faces criticism from both international and local communities for its lack of engagement with grassroots groups. Therefore, it may be more accurate to say that China's developmental peace is a style of Asian peacebuilding that has traits of or the potential for hybrid peacebuilding. China is aware that no standardised template of peacebuilding can address the wide variety of different conflict scenarios, and that peacebuilding must be adaptive to the different types of conflict faced in different regions.

As the second largest economy in the world, China is keen to be an active player in international peacebuilding. In Myanmar, where China was traditionally constrained by its non-intervention principle, the Chinese government was eventually compelled to address the root problems of ethnic unrest as border clashes became more serious, causing casualties among Chinese citizens. China's peacebuilding goal in Myanmar was to increase the resilience of local ethnic groups through the BRI's CMEC so that these ethnic groups longer had to compete with the Tatmadaw for scarce resources. China has engaged with gatekeepers such as the UWSA and maintained friendly relationships with these gatekeepers, leading to a type of development in Wa State that made the state look like a Chinese province. In addition, China has not forgotten its fundamental principle of non-intervention, as seen in the fact that it continues to engage with the Tatmadaw to convince both sides to cease violence to allow development to occur in Myanmar under the BRI. 
To enable development in Afghanistan, China must collaborate with its local economic and strategic partner, Pakistan, because the conflict in Afghanistan is a cross-border regional problem for both China and Pakistan. Through mediating the peace process between Pakistan and Afghanistan, China created the opportunity to engage with the Taliban, who were the key gatekeepers, and to address the root cause of the instability in Afghanistan. Because the Taliban are competing with the Afghan government in Kabul as a provider of public goods, the Taliban are more interested in the peace and development that the BRI offers. Given this interest, the Taliban could be transformed from a peace-spoiler to a bridge-builder because they want to attract more Chinese investment in the areas they occupy.

However, China's developmental peace also attracts criticism. The lack of the presence of Chinese NGOs at the grassroots level of the host country severely hinders China's ability to deliver aid to grassroots communities that are located away from the cities that receive Chinese aid and are the focus of BRI projects. Even when China attempts to remedy this through its SOEs to directly target remote communities in the host country, the negative image of China held by the people in countries such as Myanmar and Afghanistan makes it difficult for China to effectively deliver aid in such areas. China has also been criticised for not placing sufficient emphasis on the importance of human rights when it has served as a mediator. However, this criticism mostly arises because of the mismatch between China and the West over what constitutes basic human rights, and which aspect of basic human rights must be prioritised. The Chinese focus more on the physical side of human rights, prioritising providing grassroots groups with the right to economic development and to live a life in dignity because for China, economic development is one of the best ways to realise human dignity. Meanwhile the West, puts more priority on ideas such as human rights and democracy, with economic development coming afterwards.

As conflict situations change around the world, processes of peacebuilding must continue to adapt and evolve. Complex conflicts involving ethnic minorities in Myanmar and non-state actors in Afghanistan can no longer be solved through a standardised approach of expanding liberal institutions as guided by the model of liberal peacebuilding. New approaches such as hybrid peacebuilding, which places strong emphasis on the interactive nature of the top-down and bottom-up process, and adaptive peacebuilding, which changes the course according to the needs 
of the society concerned, are considered vital for peace to be sustainable. China has employed the model of developmental peace and attempted to apply it to neighbouring countries suffering from conflict, such as Myanmar and Afghanistan, through collaborating with its neighbours, Bangladesh and Pakistan, respectively. China's developmental peace shares many traits and similarities with the Japanese style of peacebuilding, which will be elaborated in the following chapter of this book. Unlike liberal peacebuilding, China's developmental peace does not apply a standardised approach, but treats each conflict as a unique situation that requires China to continue adapting its approach to ensure it is responsive to changing realities on the ground. In this sense, China's developmental peace is adaptive. However, this developmental peace needs to be improved so that it can achieve closer engagement with the grassroots level, transforming China's developmental peace into a fully developed model of hybrid peacebuilding.

\section{REFERENCES}

Abb, P. (2018). China's Emergence as a Peacebuilding Actor: From 'Peaceful Development' to 'Developmental Peace'? The Asia Dialogue. http://the asiadialogue.com/2018/12/24/chinas-emergence-as-a-peacebuilding-actorfrom-peaceful-development-to-developmental-peace/.

Akhtar, N. (2008). Pakistan, Afghanistan and the Taliban. International Journal on World Peace, 25(4), 49-73.

Biberman, Y., \& Schwartz, J. (2019). China and Pakistan Have Struck a Devil's Bargain with Militias. Foreign Policy. https://foreignpolicy.com/2019/04/ 05/china-and-pakistan-have-struck-a-devils-bargain-with-militants/.

Bokhari, F. (2019) Afghanistan Peace Talks Open Way for China Belt and Road. Nikkei. https://asia.nikkei.com/Spotlight/Belt-and-Road/Afghan istan-peace-talks-open-way-for-China-s-Belt-and-Road.

Butler, D. M., \& Wheeler, T. (2012) China and Conflict-affected StatesBetween Principle and Pragmatism. Saferworld. https://assets.publishing.ser vice.gov.uk/media/57a08a9a40f0b652dd0007ee/FAB-Chinas-approach.pdf.

Chen, H. P., \& Ning, W. (2020). China-Myanmar Relations from the Perspective of National Interest Theory-Opportunities and Challenges of ChinaMyanmar Cooperation During the Government of NLD. Asia-Pacific Security and Maritime Affairs, 1, 100-112.

de Coning, C. (2018). Adaptive Peacebuilding. International Affairs, 94(2), 301-317.

Dunn, C., Lin, J., \& Kui, P. (2016). Chinese Investments in Myanmar-A Scoping Study. China Going Global Series. https://www.researchgate.net/ publication/305326039_Chinese_Investments_in_Myanmar_a_Scoping_ Study_China_going_global_series. 
Dupree, N. H. (2002). Cultural Heritage and National Identity in Afghanistan. Third World Quarterly, 23(5), 977-989.

Embassy of the People's Republic of China in the United States of America. (2019). Wang $\Upsilon_{i}$ Meets with Foreign Minister Salabuddin Rabbani of Afghanistan. Embassy of the People's Republic of China in the United States of America. http://www.china-embassy.org/eng/zgyw/tl696433.htm.

Encyclopaedia Britannica. (2017). Eclecticism. Encyclopaedia Britannica. https://www.britannica.com/topic/eclecticism.

Feigenbaum, E. (2018). Reluctant Stakeholder: Why China's Highly Strategic Brand Revisionism Is More Challenging Than Washington Thinks. Marco Polo. https://macropolo.org/analysis/reluctant-stakeholder-why-chinas-hig hly-strategic-brand-of-revisionism-is-more-challenging-than-washington-thi nks/.

Feldshuh, H. (2018). How China Sidelines NGOs. The Diplomat. https://the diplomat.com/2018/09/how-china-sidelines-ngos/.

Fisher, J. (2016). Drugs, Money and Wildlife in Myanmar's Most Secret State. BBC. https://www.bbc.com/news/world-asia-37996473.

Geng, L. X. (2006). Sino-Myanmar Relations: Analysis and Prospects. The Culture Mandala, 7(2), 1-17.

Global Times. (2017). China Wishes Earliest Achievement of Afghan National Reconciliation: FM. Global Times. http://www.globaltimes.cn/content/105 3321.shtml.

Glosserman, B. (2020). The Real China Challenge. The Japan Times. https:// www.japantimes.co.jp/opinion/2020/01/07/commentary/world-commen tary/real-china-challenge/.

He, K. R. (2019a). Afghanistan Clan Politics and the Mode of Governing of a Modern State. Social Sciences in Yunnan, 2, 97-104.

He, Y. (2019b). China Rising and Its Changing Policy on UN Peacekeeping. In C. de Coning (Ed.), United Nations Peace Operations in a Changing Global Order (pp. 253-276). Gewerbestrasse: Palgrave Macmillan.

Hu, C. Y. (2018). China's Impact in the Situation of Afghanistan (论中国在当 前阿富汗局势中的作用). Journal of the Party School of XPCC of C.P.C. (兵团 党校学报), 3, 67-72.

Hudson Institute. (2018). Remarks by Vice President Pence on the Administration's Policy Towards China. The Hudson Institute. https://www.whiteh ouse.gov/briefings-statements/remarks-vice-president-pence-administrationspolicy-toward-china/.

Hui, M. (2019). Photos: How China Erupted into Anti-American Rage 20 Years Ago. Quartz. https://qz.com/1614273/photos-anti-us-protests-afterbombing-of-belgrade-chinese-embassy-in-1999/. 
Human Rights Watch. (2018). Bangladesh: Halt Rohingya Repatriation Plan. Human Rights Watch. https://www.hrw.org/news/2018/11/15/bangla desh-halt-rohingya-repatriation-plan.

International Crisis Group (ICG). (2017). China's Foreign Policy Experiment in South Sudan. International Crisis Group. https://www.crisisgroup.org/afr $\mathrm{ica} /$ horn-africa/south-sudan/288-china-s-foreign-policy-experiment-southsudan.

Jackson, A. (2018). The Taliban's Fight for Hearts and Minds. Foreign Policy. https://foreignpolicy.com/2018/09/12/the-talibans-fight-for-heartsand-minds-aghanistan/.

Japan International Cooperation Agency (JICA). (n.d.). Tokyo Center: Collaboration with NGOs. JICA. https://www.jica.go.jp/tokyo/english/office/activi ties/activities_05.html.

Japan Platform. (2019). Japan Platform. https://www.japanplatform.org/lib/ data/JPF_en.pdf.

Johnston, A. I. (2003). Is China a Status Quo Power? International Society, $27(4), 5-56$.

Joy, A. (2018). Understanding China's Response to the Rakbine Crisis. United States Institute of Peace. https://www.usip.org/sites/default/files/2018-02/ sr419-understanding-chinas-response-to-the-rakhine-crisis.pdf.

Kagawa, M. (2020). The Role of Rebel Gatekeepers in the Mid-space in Peacebuilding: A Case Study of Bangsamoro. In Y. Uesugi (Ed.), Hybrid Peacebuilding in Asia (pp. 61-87). New York: Palgrave Macmillan.

Kasai, T., \& Adams, B. (2018). Japan Shouldn't Act Like China in Cambodia. Japan Times. https://www.japantimes.co.jp/opinion/2019/03/27/commen tary/japan-commentary/japan-shouldnt-act-like-china-cambodia/.

Khalil, A. B. (2018). The History of Chinese Mediation Between Afghanistan and Pakistan. The Diplomat. https://thediplomat.com/2018/01/the-his tory-of-chinese-mediation-between-afghanistan-and-pakistan/.

Limpach, S., \& Michaelowa, K. (2010). The Impact of the World Bank and IMF Programs on Democratization in Developing Countries. Centre for Comparative and International Studies (CIS), 62(1), 1-62.

Lin, Y. M. (2019). China's Further Constructive Intervention for Positive Momentum in Afghanistan's Peace Process (中国进一步建设性介入为阿富汗 和平进程注入正能量). World Affairs, 15, 38-39.

Lintner, B. (2019). The United Wa State Army and Burma's Peace Process. United Institute of Peace. https://www.usip.org/publications/2019/04/uni ted-wa-state-army-and-burmas-peace-process.

Luhmann, N. (1990). Essays on Self-reference. New York: Columbia University Press. 
Mac Ginty, R., \& Sanghera, G. (2012). Hybridity Peacebuilding and Development: An Introduction. Journal of Peacebuilding \& Development, 7(2), 3-8.

Matyok, T., Senehi, J., \& Byrne, S. (2011). Critical Issues in Peace and Conflict Studies: Theory Practice and Pedagogy. Lanham: Rowman \& Littlefield Education.

Ministry of Foreign Affairs (MOFA) of Islamic Republic of Afghanistan. (2019). Joint Statement of the 3rd China-Pakistan-Afghanistan Foreign Ministers' Dialogue. Ministry of Foreign Affairs of Afghanistan. https://www.mfa.gov. af/statements/1272-joint-statement-of-the-3rd-china-afghanistan-pakistanforeign-ministers-dialogue.html.

MOFA of Japan. (2017). MOFA Diplomatic Bluebook Chapter 4: Japan's Public Diplomacy open to the Public. Ministry of Foreign Affairs of Japan. https://www.mofa.go.jp/policy/other/bluebook/2017/html/cha pter4/c040102.html.

MOFA of the People's Republic of China. (2014). China's Initiation of the Five Principles of Peaceful Coexistence. Ministry of Foreign Affairs of the People's Republic of China. https://www.fmprc.gov.cn/mfa_eng/ziliao_665 539/3602_665543/3604_665547/tl 18053.shtml.

MOFA of the People's Republic of China. (2017). The 1st China-AfghanistanPakistan Foreign Minister's Dialogue Convenes. Ministry of Foreign Affairs of the People's Republic of China. https://www.fmprc.gov.cn/mfa_eng/zxxx_6 62805/t1522541.shtml.

MOFA of the People's Republic of China. (2018). Joint Statement of the 2nd Afghanistan-China-Pakistan Foreign Minister's Dialogue. Ministry of Foreign Affairs of the People's Republic of China. https://www.fmprc.gov.cn/mfa eng/wjdt_665385/2649_665393/t1622631.shtml.

Notezai, M. A. (2019). Balochistan's Role in the Afghanistan Quagmire. The Diplomat. https://thediplomat.com/2019/08/balochistans-role-in-theafghanistan-quagmire/.

Orakzai, S. B. (2015). Neo-Liberal Peacebuilding in Libya. In J. I. Lahai \& T. Lyon (Eds.), African Frontiers: Insurgency, Governance and Peacebuilding in Postcolonial States (pp. 143-155). Farnham: Ashgate Publishing Limited.

Panda, A. (2015). Myanmar Bombings in Yunnan Killed 4 Chinese. The Diplomat. https://thediplomat.com/2015/03/its-official-myanmar-bom bings-in-yunnan-killed-4-chinese-citizens/.

Rapoza, K. (2019). China Has Forgiven Nearly \$10 Billion in Debt. Cuba Accounts for Over Half. Forbes. https://www.forbes.com/sites/kenrapoza/ 2019/05/29/china-has-forgiven-nearly-10-billion-in-debt-cuba-accountsfor-over-half/\#28165adf615b. 
Reuters. (2012). Japan to Write off Myanmar Debts, Restart Loans. Reuters. https://www.reuters.com/article/us-myanmar-japan/japan-to-write-off-mya nmar-debt-restart-loans-idUSBRE83K07M20120421.

Richmond, O. P., \& Tellidis, I. (2014). Emerging Actors in International Peacebuilding and State building: Status Quo or Critical States? Global Governance, 20(4), 563-584.

Ruan, Z. Z. (2012). Responsible Protection: Building a Safer World. China Institute of International Studies. http://www.ciis.org.cn/english/2012-06/15/ content_5090912.htm.

Sarwar, M. (2020). China Ramps Up Role in Afghanistan Ahead of U.S. Withdrawal. Gandhara. https://gandhara.rferl.org/a/china-ramps-up-role-in-afg hanistan-ahead-of-u-s-withdrawal-/30594555.html.

Sediqi, A. Q. (2019) Afghan Rivals to Meet in China after U.S. Talks Stall. Reuters. https://www.reuters.com/article/us-afghanistan-talibanchina/afghan-rivals-to-meet-in-china-after-us-talks-stall-idUSKBN1X20C7.

Sun, Y. (2013). China's Intervention in the Myanmar-Kachin Peace Talks. Brookings. https://www.brookings.edu/articles/chinas-interventionin-the-myanmar-kachin-peace-talks/.

Sun, Y. X. (2014). Global Times Interview with China's First Special Envoy to Afghanistan Sun Yuxi (我国首任阿富汗事务特使孙玉胥做客环球网). Global Times. https://opinion.huanqiu.com/article/9CaKrnJFmJZ.

Sun, Y. (2019). Peace through Development: China's Experiment in Myanmar. Frontier Myanmar. https://frontiermyanmar.net/en/peace-through-develo pment-chinas-experiment-in-myanmar.

Thiha, A. (2020) China Pledges 4 Billion Yuan in Aid to Myanmar. The Irrawaddy. https://www.irrawaddy.com/news/burma/china-pledges-4billion-yuan-aid-myanmar.html.

Tiezzi, S. (2015). More Chinese Citizens Injured in Spillover From Myanmar Conflict. The Diplomat. https://thediplomat.com/2015/05/more-chinesecitizens-injured-in-spillover-from-myanmar-conflict/.

Uesugi, Y. (2020). Introduction. In Y. Uesugi (Ed.), Hybrid Peacebuilding in Asia (pp. 1-14). Cham: Palgrave Macmillan.

Uesugi, Y., \& Kagawa, M. (2020). A Typology of Mid-space Local Bridgebuilders. In Y. Uesugi (Ed.), Hybrid Peacebuilding in Asia (pp. 37-60). Cham: Palgrave Macmillan.

Waldman, M. (2010). The Sun in the Sky: The Relationship Between Pakistan's ISI and Afghan Insurgents. Crisis States Discussion Papers, 18, 1-27.

Wang, C. Y. (2018). The Chinese Communist Party's Relationship with the Khmer Rouge in the $1970 \mathrm{~s}$. Woodrow Wilson International Center for Scholars. https://www.wilsoncenter.org/publication/the-chinese-communist-partys-rel ationship-the-khmer-rouge-the-1970s-ideological-victory. 
Wolf, C., Wang, X., \& Warner, E. (2013). China's Foreign Aid and Governmentsponsored Investment Activities-Scale, Content, Destinations, and Implications. https://www.rand.org/pubs/research_reports/RRl18.html.

Xi, J. P. (2010). Critical Study on the Theory of Socialism with Chinese Characteristics and Efforts to Think from a Marxist Perspective (深入学习中国 特色社会主义理论体系努力掌握马克思主义立场观点方法). Qiushi Magazine (求是杂志), 7, 17-24.

Xi, J. P. (2020). Full Text: 2020 New Year Speech by President Xi Jinping. China Global Television Network. https://news.cgtn.com/news/2019-12-31/Fulltext-Chinese-President-Xi-Jinping-s-2020-New-Year-speech-MSnhLaJmIE/ index.html.

Xinhua. (2018a). China Donates Prefabricated Houses for Displaced People in Myanmar's Rakhine State. Xinhua. http://www.xinhuanet.com/english/ 2018-01/07/c_136877520.htm.

Xinhua. (2018b). Wang Yi: China's Participation in Hotspot Issues Maintains the Stance of 'Do what We Can, Don't do what we Can' $t$ ' (王毅:中国参与解 决热点问题 始终坚持有所为也有所不为). Xinhuanet (新华网). http://www. xinhuanet.com/world/2018-03/08/c_137021769.htm.

Xinhua. (2019a). China on Behalf of 139 Countries Calls for Full Realization of Right to Development at the UN. Xinhuanet. http://www.xinhuanet.com/ english/2019-09/14/c_138390990.htm.

Xinhua. (2019b). Envoy Elaborates China's Position on Afghanistan. Xinhuanet. http://www.xinhuanet.com/english/2019-11/28/c_138588110.htm.

Xinhua. (2020). China Welcomes U.S.-Taliban Peace Deal: FM Spokesperson. Xinhuanet. http://www.xinhuanet.com/english/2020-03/02/c_1388 36242.htm.

Yao, Y., \& Zhang, Y. Y. (2018). Public Perceptions of Chinese and Investments in Myanmar and Its Political Consequences: A Survey Experimental Approach. International Growth Centre. https://www.theigc.org/wp-content/uploads/ 2018/06/Yao-Zhang-2018-Policy-Brief.pdf.

Zhang, T. (2020). Diarchy of Myanmar in Post-military Era and Its Foreign Effects (后军人时代缅甸的 “双头政治” 及其外交影响). SoutheastAsia Research (东南亚研究), 1, 33-68.

Zhao, H. (2013). China's Afghani Policy: The Forming of the 'March West' Strategy. Journal of East Asian Affairs, 27(2), 1-29.

Zhou, E. L. (1964). The Chinese Government's Eight Principles for Economic Aid and Technical Assistance to Other Countries. Wilson Center. https://digitalar chive.wilsoncenter.org/document/121560.pdf. 
Open Access This chapter is licensed under the terms of the Creative Commons Attribution 4.0 International License (http://creativecommons.org/licenses/ by $/ 4.0 /$ ), which permits use, sharing, adaptation, distribution and reproduction in any medium or format, as long as you give appropriate credit to the original author(s) and the source, provide a link to the Creative Commons license and indicate if changes were made.

The images or other third party material in this chapter are included in the chapter's Creative Commons license, unless indicated otherwise in a credit line to the material. If material is not included in the chapter's Creative Commons license and your intended use is not permitted by statutory regulation or exceeds the permitted use, you will need to obtain permission directly from the copyright holder.

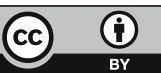

